Original Research Paper

\title{
Pemanfaatan Hasil Pengembangan Modul Kimia Berbasis Etnosains Untuk Menanamkan Sikap Konservasi Lingkungan di Sekolah MAN 2 Lombok Tengah
}

\author{
Rizki Utari $^{* 1}$, Yayuk Andayani ${ }^{2}$, Lalu Rudyat Telly Savalas², Yunita Arian Sani Anwar ${ }^{2}$ \\ ${ }^{1}$ Program Studi Magister Pendidikan IPA Universitas Mataram, Mataram. \\ ${ }^{2}$ Program Studi Pendidikan Kimia FKIPA Universitas Mataram, Mataram.
}

DOI: https://doi.org/10.29303/jpmpi.v3i2.593

Sitasi: Utari, R., Andayani, Y., Savalas, L. R. T., \& Anwar, Y. A. S. (2021). Pemanfaatan Hasil Pengembangan Modul Kimia Berbasis Etnosains Untuk Menanamkan Sikap Konservasi Lingkungan di Sekolah MAN 2 Lombok Tengah. Jurnal Pengabdian Magister Pendidikan IPA, 4(1)

Article history

Received: 02 Desember 2020

Revised: 29 Desember 2020

Accepted: 18 Januari 2021

*Corresponding Author: Rizki Utari, Program Studi Magister Pendidikan IPA Universitas

Mataram, Mataram, Indonesia

Email: rizkiutari408@gmail.com

\begin{abstract}
Abstrak: Artikel ini membahas tentang pemanfaatan hasil pengembangan modul kimia dengan pendekatan etnosains pada materi kimia SMA. Pemanfaatan hasil ini dilakukan di MAN 2 Lombok Tengah. Pemilihan sampel dilakukan dengan teknik purposive sampling. Pemanfaatan hasil pengembangan ini termasuk penelitian deskriptif dengan pendekatan kuantitatif, melibatkan peserta didik di MAN 2 Lombok Tengah sebanyak 110 responden. Data respon peserta didik dikumpulkan menggunakan angket dengan skala Likert dan dianalisis dengan persentase skor yang kemudian diinterpretasikan dengan kriteria kategori respon. Pemanfaatan hasil pengembangan menunjukkan bahwa respon peserta didik terhadap modul kimia dengan pendekatan etnosains termasuk dalam kriteria baik dengan skor sebesar 3.00. Artinya peserta didik memberika respon yang positif terhadap modul, sehingga pemanfaatan hasil pengembangan modul kimia berbasis etnosains yang dikembangkan dapat digunakan untuk menanamkan sikap konservasi lingkungan peserta didik di MAN 2 Lombok Tengah.
\end{abstract}

Kata kunci: : Respon peserta didik, Modul Kimia, Etnosains, Sikap konservasi lingkungan

\section{Pendahuluan}

Etnosains merupakan pengetahuan asli (indigenous science) yang dimiliki oleh suatu komunitas budaya dan bahasa tertentu (Okechukwu, 2014; Abonyi, 2017) yang berkaitan dengan peta kognitif dari suatu masyarakat (Sudarmin, 2014). Pembelajaran menggunakan pendekatan etnosains sangat penting dimiliki oleh siswa karena keberhasilan proses pembelajaran sains di sekolah sangat dipengaruhi oleh latar belakang budaya yang dimiliki siswa atau masyarakat di mana sekolah tersebut berada (Aikenhead dan Jegede, 1999); Baker et al., 1995).

Pembelajaran berbasis etnosains ini akan mengenalkan peserta didik bahwa terdapat fenomena yang dipercaya oleh masyarakat yang dapat dipadukan dengan materi-materi sains ilmiah yang ada sebagai ilmu pengetahuan (Atmojo, 2012). Oleh karena itu sangat penting bagi guru untuk menanamkan konsep sains ilmiah yang belum diformalkan. Tingkat pemahaman konsep guru ini akan menentukan profesionalismenya dalam mengajar (Andayani et al., 2018).

Keseimbangan dari keduanya akan menghasilkan pembelajaran yang bermakna. Hal itu didukung oleh Stanley \& Brickhouse (2001) yang menyarankan agar guru menyeimbangkan pembelajaran sains di sekolah dengan pengetahuan sains tradisional dalam bentuk lintas budaya sebagai sumber belajar.

Pengintegrasian pembelajaran sains asli masyarakat kedalam pembelajaran di sekolah sangat penting diterapkan. Mengingat saat ini semakin menurunnya nilai dan norma yang berlaku dimasyarakat (Utari et al., 2020). Oleh karena itu perlu dikenalkan sejak dini khususnya kepada peserta didik sebagai generasi penerus melalui bahan ajar berupa modul. Harapannya modul 
tersebut dapat menenamkan sikap konservasi lingkungan peserta didik.

Hasil obeservasi di MAN 2 Lombok Tengah diperoleh bahwa bahan ajar yang diterapkan masih belum mampu mengintegrasikan sains asli masyarakat kedalam pembelajaran di sekolah. Hal ini dikarenakan peserta didik sekitar 76,5\% peserta didik tidak menggunakan buku pegangan ketika belajar kimia, $76,5 \%$ tidak mengetahui tentang pembelajaran etnosains, dan $58,8 \%$ senang melaksanakan praktikum, dan $94,1 \%$ berpendapat bahwa praktikum kimia jarang dilaksanakan. Peserta didik yang senang melaksanakan praktikum ini perlu disediakan wadah untuk melaksanakan praktikum yang dekat dengan dunia mereka seharisehari.

Permasalahan lainnya yang ditemukan di lapangan adalah kebiasaan membuang sampah sembarangan dan tidak hemat energi. Hal ini mengindikasikan bahwa perlu adanya tindak lanjut agar mereka dikenalkan dengan pembelajaran yang dekat dengan lingkungan dan dapat menanamkan nilai-nilai arif yang terkandung didalamnya.

Berdasarkan permasalahan yang diperoleh maka peneliti tertarik untuk melihat pemanfaatan hasil pengembangan modul kimia.berbasis etnosains. Pemanfaatan hasil ini sebagai alat penilaian untuk menanamkan sikap konservasi lingkungan peserta didik. Penilaian yang dilakukan untuk menguji kebermanfaatan modul sehingga praktis digunakan dalam pembelajaran kimia di sekolah.

\section{Bahan dan Metode}

\section{a. Waktu dan Tempat Pelaksanaan}

Pemanfaatan hasil pengembangan ini dilaksanakan pada tanggal 25 Maret 2020 pada peserta didik kelas XI sebanyak 110 orang. Lokasi sekolah di MAN 2 Lombok Tengah. Pembelajaran dilakukan secara daring dalam WAG (Whatssapp Group) dan diawasi oleh guru mata pelajaran.

\section{b. Alat dan Bahan}

Media pembelajaran berupa modul disusun sesuai dengan kebutuhan peserta didik, diantaranya modul dapat digunkaan untuk belajar mandiri, berisi materi hidrolisis garam yang dihubungkan dengan proses pembuatan garam di desa Cendimanik, Sekotong, dan dilengkapi dengan pojok konservasi yang dekat dengan lingkungan.
Modul didesain dalam bentuk booklet yang praktis, menarik, dan mudah dipahami dengan ukuran kertas 17,6 x $25 \mathrm{~cm}$ menggunakan kertas B5, cover modul full warna, tebal 65 halaman, dan dalam bentuk e-module. Modul berisi 3 kegiatan belajar yang uatama yakni aktivitas etnosains, materi pelajaran kimia, dan evaluasi. Setiap kegiatan dibagi menjadi beberapa komponen-komponen yang dikemas dalam bentuk fitur yang menarik.

Modul ini didukung oleh media lainnya seperti video, gambar, dan power point yang dikirimkan ke group whatsapp (WAG) peserta didik. Modul yang disusun dalam bentuk e-module yang dibagikan satu minggu sebelum pembelajaran daring dimulai. Selain itu juga disiapkan perangkat pembelajaran lainnya seperti LKPD berbasis etnosains, dibagikan dikelompok belajar, lembar observasi dan lembar angket disebarkan melalui google form yang disi oleh peserta didik. Modul kimia berbasis etnosains yang dikembangkan terlampir (Lampiran 1).

\section{c. Penilaian Hasil Belajar}

Penelitian ini merupakan penelitian deskriptif dengan pendekatan kuantitatif. Data pada penelitian ini berisi tentang pengetahuan peserta didik tentang etnosains, pengalaman mereka dalam menggunakan modul sebagai sumber belajar, manfaat yang diperoleh dalam sikap dan perilaku konservasi, dan karakter positif lainnya. Data selanjutnya dianalisis secara deskriptif untuk menggambarkan respon peserta didik terhadap modul kimia bermuatan etnosains.

Katagori respon peserta didik menggunakan tabel kreteria, sedangkan pilihan jawaban kuesioner menggunakan skala Likert dengan tingkatan respon dinyatakan dalam bentuk skor. Skor tertinggi memperoleh skor 4 (empat) dan terendah skor 1 (satu) untuk pernyataan positif dan sebaliknya untuk pernyataan negatif. Hasil skor tersebut kemudian dicari nilai tanggapan dan dikonsultasikan berdasarkan tabel penskoran.

Nilai tanggapan $=\frac{\text { Jumla } h \text { skor yang diperole } h}{\text { jumla } h \text { skor mak simal }} \times 4$ 
Penentuan konversi skor tanggapan peserta didik menggunakan kriteria pada Tabel 1.

Tabel 1. Kriteria Tanggapan Peserta Didik

\begin{tabular}{ll}
\hline Nilai Tanggapan & Kriteria \\
\hline $3,25<\mathrm{x} \leq 4,0$ & Sangat Baik \\
$2,50<\mathrm{x} \leq 3,25$ & Baik \\
$1,75<\mathrm{x} \leq 2,50$ & Cukup Baik \\
$1,0<\mathrm{x} \leq 1,75$ & Kurang Baik \\
\hline
\end{tabular}

(Susilo, 2015)

\section{Hasil dan Pembahasan}

\section{Rancangan Modul}

Modul yang dikembangkan dirancang agar peserta didik dapat belajar secara mandiri. Didalam modul sudah tersedia petunjuk penggunaan dan tujuantujuan yang harus dicapai dalam setiap kegiatan dan terdapat umpan balik untuk mengetahui tingkat penguasaan materi yang diajarkan. Modul berisi tiga kegiatan belajar yakni aktivitas etnosains, materi yang diajarkan, dan evaluasi. Didalamnya dilengkapi fitur-fitur seperti pojok konservasi, aktivitas etnosains, ayo bereksperimen, ayo berjelajah, uji kompetensi, tindak lanjut, dan beberapa fitur menarik lainnya. Kelengkapan fiturfitur ini menjadikan modul ini dapat digunakan dalam pembelajaran. Berikut salah satu tampilan fitur yang ada dalam modul kimia.

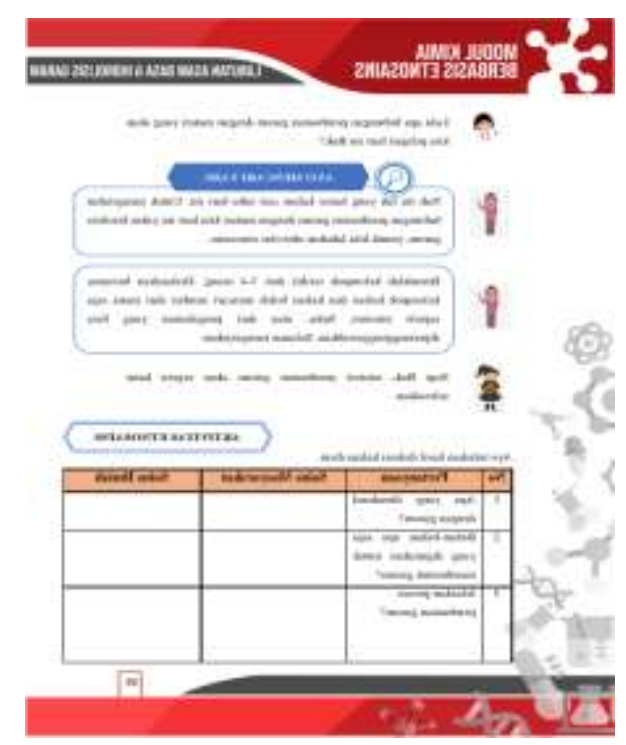

Gambar 1 Tampilan Fitur Aktivitas Etnosains
Dalam aktivitas etnosains peserta didik akan diarahkan agar dapat merekonstruksikan pengetahuan sains masyarakat kepengetahuan sains ilmiah. Tahapannya peserta didik akan disajikan permasalahan awal dan dilakukan diskusi singkat mengenai kebiasaan masyarakat (identifikasi) dalam bentuk percakapan pendek yang sudah tersedia dimodul, selanjutnya hasil penelusuran tersebut akan diarahkan untuk menghubungkannya dengn konsep kimia dalam kehidupan sehari-hari. Hasil kajian etnosains tersebut menunjukkan adanya nilai kearifan lokal dan potensi etnosains yang dapat diterapkan dalam pembelajaran sains.

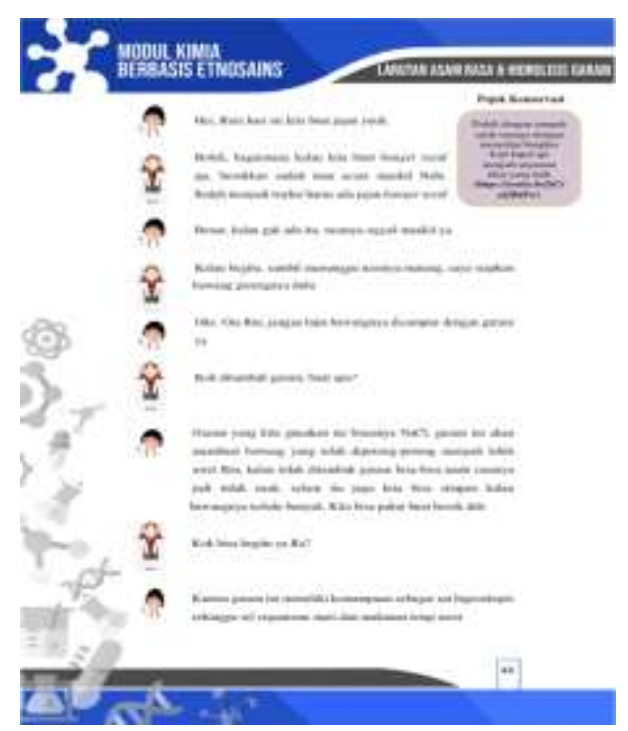

Gambar 2. Tampilan Fitur Pojok Konservasi

Pojok konservasi ini bertujuan untuk memberikan informasi sikap konservasi lingkungan yang menginspirasi dan dijadikan sebagai pelajaran bagi peserta didik, melalui informasi inilah harapannya dapat membentuk pola pikir dan dapat melahirkan tindakan yang akan membentuk kebiasaan peserta didik.

\section{Pelaksanaan Pemanfaatan Hasil Pengembangan Modul Kimia}

Modul kimia berbasis etnosains yang dikembangkan dilaksanakan secara daring dengan menggunakan model problem based learning. Model ini digunakan karena pembelajaran berbasis etnosains menekankan pada permasalahan yang berhubungan dengan kearifan lokal. Selain itu juga membekali peserta didik dengan nilai-nilai karakter yang ada agar diperoleh kegiatan pembelajaran yang bermakna. 
Pelaksanaan hasil pemanfaatan modul kimia yang telah dikembangkan disesuaikan dengan kurikulum 2013 dan tuntutan saat ini yang menekankan pada aspek sosial. Adapun tahapan kegiatan mulai dari kegiatan awal, kegiatan inti, dan penutup. Kegiatan awal diberikan modul yang berisi aktivitas etnosains dan permasalahan yang ada di lingkungan sekitar sebagai bentuk penguatan nilai budaya. Kegiatan inti yakni berisi tentang penyajian materi, diskusi dan tanya jawab. Kegiatan terakhir yakni kegiatan penutup berupa evaluasi hasil belajar peserta didik. Tahapan kegiatan tersebut dapat dilihat pada gambar berikut.

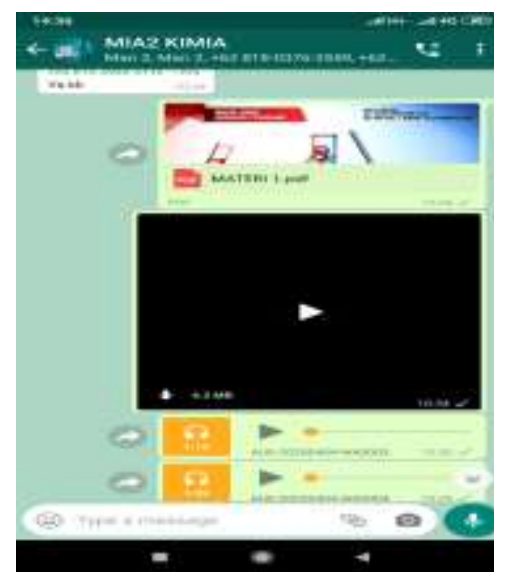

Gambar 3. Kegiatan Awal

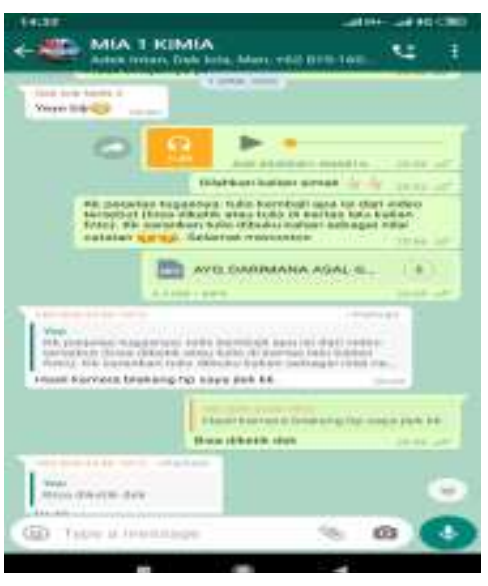

Gambar 4. Kegiatan Inti

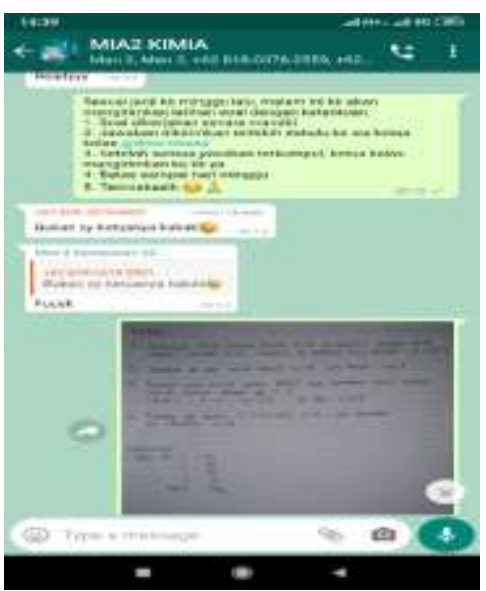

Gambar 5. Kegiatan Penutup

Berdasarkan gambar-gambar di atas menunjukkan bahwa pemanfaatan hasil modul kimia yang dikembangkan diajarkan pada materi hidrolisis garam. Pada kegiatan awal dipaparkan penggunaan e-module dan penjelasan proses pelaksanaannya. Pada gambar 4 menunjukkan salah satu contoh kegiatan inti yakni peserta didik disajikan video animasi proses pembuatan garam dan diminta untuk menganalisisnya. Selain itu juga mereka diminta membaca percakapan yang tertera di modul. Kegiatan ini akan mengarahkan peserta didik untuk memecahkan permasalah yang ada dalam kolom aktivitas etnosains.

Kegiatan terakhir yakni penutup, terlihat pada gambar 5. Gambar 5 menunjukkan penggunaan instrumen evaluasi berupa soal uraian. Evaluasi ini bertujuan untuk melihat tingkat hasil pemanfaatan modul kimia berbasis etnosains yang telah dikembangkan.

\section{Respon Peserta Didik terhadap Modul}

Respon peserta didik terhadap modul berpendekatan etnosains dinilai berdasarkan beberapa indikator yakni kemudahan dalam memahami, minat, sikap mandiri, penyajian modul, dan konsep etnosains. Berdasarkan data yang diperoleh rata-rata respon peserta didik terhadap aqmodul dalam kategori baik dengan nilai sebesar 3.00. Indikator minat terhadap modul memiliki nilai tanggapan paling besar yakni sebesar 3.31 dalam kategori baik dan nilai terendah pada indikator pengetahuan tentang etnosains sebesar 2.41 dalam kategori cukup baik. Nilai tanggapan dari masing-masing indikator dapat dilihat pada Grafik 1. 


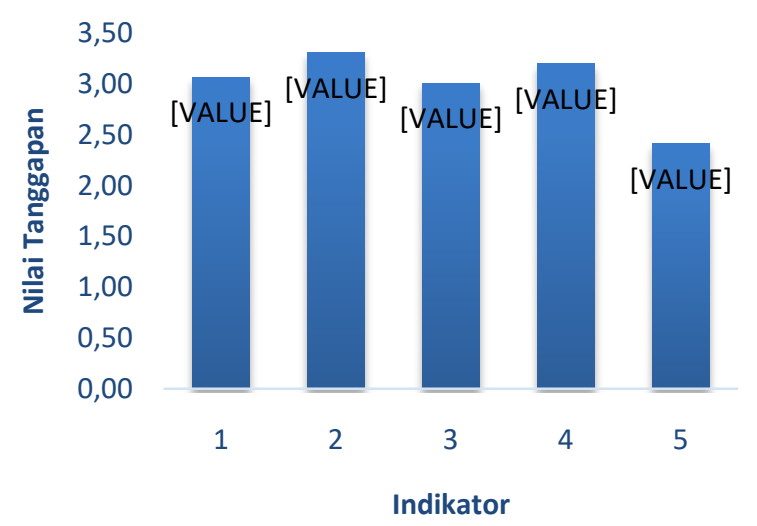

Grafik 1 Nilai Respon Terhadap Modul Kimia

Keterangan Indikator:

1. Kemudahan memahami modul

2. Minat terhadap modul

3. Sikap kemandirian belajar

4. Penyajian modul

5. Etnosains

Berdasarkan Grafik 1, secara keseluruhan peserta didik memberikan respon yang positif terhadap modul kimia yang dikembangkan. Terlihat bahawa indikator ke-5 (lima) memperoleh respon yang paling rendah dibandingkan dengan indikator lainnya. Hal ini menunjukkan bahwa pengetahuan peserta didik tentang pembelajaran etnosains masih rendah. Jadi, tidak menutup kemungkinan hasil yang diperoleh juga perlu ditingkatkan, namun terlihat ada perubahan. Mulai dari tidak mengetahui tentang pembelajaran etnosains sampai pada akhirnya penanaman sikap melalui modul berbasis etnosain dalam kategori baik.

Berdasarkan data respon peserta didik terhadap modul ini secara tidak langsung dapat dihubungkan dengan sikap konservasi lingkungan. Hal ini disebabkan karena modul sudah dirancang untuk menanamkan sikap tersebut. Artinya apabila peserta didik memberikan respon yang postif terhadap modul maka sikap dapat ditanamkan dalam diri mereka. Hasil yang diperoleh sesuai dengan hasil yang diperoleh dari peneliti yang mengkaji tentang pentingnya pembelajaran etnosains dalam proses pembelajaran peserta didik (Suardana et al, 2013; Shidiq, 2016; Pamungkas et al, 2017).

Penanaman sikap ini tentunya tidak dapat dibentuk serta merta dengan sendirinya, melainkan harus diberikan pemahaman dan pengalaman terus menerus hingga membentuk kebiasaan (Abidinsyah, 2013; Rahmawati, 2014).

Pembelajaran etnosains ini merupakan salah satu alternatif sebagai langkah awal untuk membentuk kebiasaan tersebut, karena dalam pembelajaran diberikan contoh yang mengkaitkan konsep kimia dengan budaya yang dipercaya secara turun temurun dipercaya oleh masyarakat. Artinya pembelajaran di sekolah memang tidak dapat dipisahkan dengan lingkungan peserta didik sehari-hari (Utari, 2020).

\section{Kesimpulan}

Berdasarkan hasil analisis dan pembahasan maka dapat disimpulkan bahwa

a. Rata-rata peserta didik memberikan respon postif dengan nilai tanggapan 3.00 dalam kategori baik.

b. Setiap indikator respon terhadap modul kimia berbasis etnosains menunjukkan kategori positif untuk digunakan dalam proses pembelajaran.

c. Modul kimia dapat digunakan untuk menanamkan sikap konservasi lingkungan peserta didik.

\section{Saran}

Saran untuk peneliti selanjutnya diharapkan dapat melakukan hasil pemanfaatan dengan mengembangkan bahan ajar yang mengangkat budaya yang berbeda dan relevan dengan pembelajaran di sekolah.

\section{Ucapan Terima Kasih}

Penelitian ini didanai oleh Direktorat Riset dan Pengabdian Masyarakat, Deputi Bidang Penguatan Riset dan Pengembangan, Kementrian Riset, Teknologi/Badan Riset dan Inovasi Nasional Sesuai dengan Kontrak Penelitian Tahun Anggaran 2020.

Nomor: 047/SP2H/LT/DRPM/2020

\section{Daftar Pustaka}

Abidinsyah. (2013). Internalisasi Peduli Lingkungan Melalui Pembelajaran Berbasis Kearifan Local (Studi di SD Antasari Besar 7 Banjarmasin) Bandung. Dissertation: Universitas Pendidikan Indonesia.

Abonyi, Okechukwu. 2017. Effect of an Ethnoscience Based Instructional Package on 
Student Conception of Scientif Phenomena. accessed on January 2020. https://www.researchgate.net/.

Andayani, Y., Hadisaputra, S., \& Hasnawati, H. (2018). Analysis of the Level of Conceptual Understanding. In Journal of Physics: Conference Series (Vol. 1095. No. 1, p. 012045). IOP Publishing.

Atmojo, S.E., (2012). Profil Keterampilan Proses Sains Dan Apresiasi Peserta didik Terhadap Profesi Pengrajin Tempe Dalam Pembelajaran Ipa Berpendekatan Etnosains. JPII. Vol.1 (2): 115-122.

Baker, D., \& Taylor, P. C. (1995) the Effect of Culture on the Learning of Science in NnWestern Countries: The Result of an Integrated Research Review. International Journal of Science Education. 17(6). 695-704.

Jegede, O. \& Aikenhead, G. (1999). Transcending Cultural Borders: Implications for Secondary Students Attitude Toward Science. Research in Science Education, 19. 155-164.

Okechukwu, S., Abonyi, Lawrence, A \& Njoku. 2014. Innovations in Science and Technology Education: A Case for Ethnoscience Based Science Classrooms. International Journal of Scientific and Engineering Research, Volume 5, Issue 1. accessed Dec 2020 : http://s3.amazonaws.

com/academia.edu.documents/ 33498416/ Innovations-in-Science-and-Technology-

Education.pdf?

Pamungkas, A. Subali, B., \& Linuwih, S. (2017). Implementasi Model Pembelajaran IPA Berbasis Kearifan Lokal Untuk Meningkatkan Kreativitas dan Hasil Belajar Siswa. Jurnal Inovasi Pendidikan IPA, 3(2), 118-127.

Rahmawati, S. U. (2014). Meningkatkan karakter peduli lingkungan melalui sekolah berbudaya lingkungan Hidup: Studi Deskriptif di SMPN 7 Bandung. Tesis. Bandung: Universitas Pendidikan Indonesia.

Shidiq, A. S. (2016). Pembelajaran Sains Kimia Berbasis Etnosains Untuk Meningkatkan Minat dan Prestasi Belajar Siswa. Proseding Seminar Nasional Kimia dan Pendidikan Kimia VIII. FKIP UNS. Surakarta: FKIP UNS.
Stanley, W.B \& N.W. Brickhouse. (2001). The Multicultural Question Revisited. Science Education.Vol.85 (I): 35-48.

Suardana, I. N. (2010). Pengembangan Model Praktikum Kimia Dasar Berbasis Budaya Bali Untuk Meningkatkan Keterampilan Berpikir Mahasiswa. Dissertation. Bandung: Universitas Pendidikan Indonesia.

Sudarmin. 2014. Model Pembelajaran Sains Berbasis Etnosains (MPSBE) untuk Menanamkan Nilai Karakter Konservasi dan Literasi Sains. Semarang: Universitas Semarang.

Susilo, H. W. (2015). Riset Kualitatif \& Aplikasi Penelitian Ilmu Keperawatan. Jakarta: Trans Info Media.

Utari, R., Andayani, Y., \& Savalas, L.R.T. (2020). Pengembangan Modul Kimia Berbasis Etnosains Dengan Mengangkat Kebiasaan Petani Garam. Jurnal Pijar MIPA. 15(5). 478481. doi: 10.29303/jpm.v15i5.

Utari, R., Andayani, Y., Savalas, L.R.T., \& Anwar, Y.A.S. (2020). Validity of Ethnoscience Based Chemistry Learning Media Emphasizing Character Values and Conservation Behavior. Jurnal Penelitian Pendidikan IPA. 7(1). 45-48. doi: https://doi.org/10.29303/jppipa.v7i1.469. 

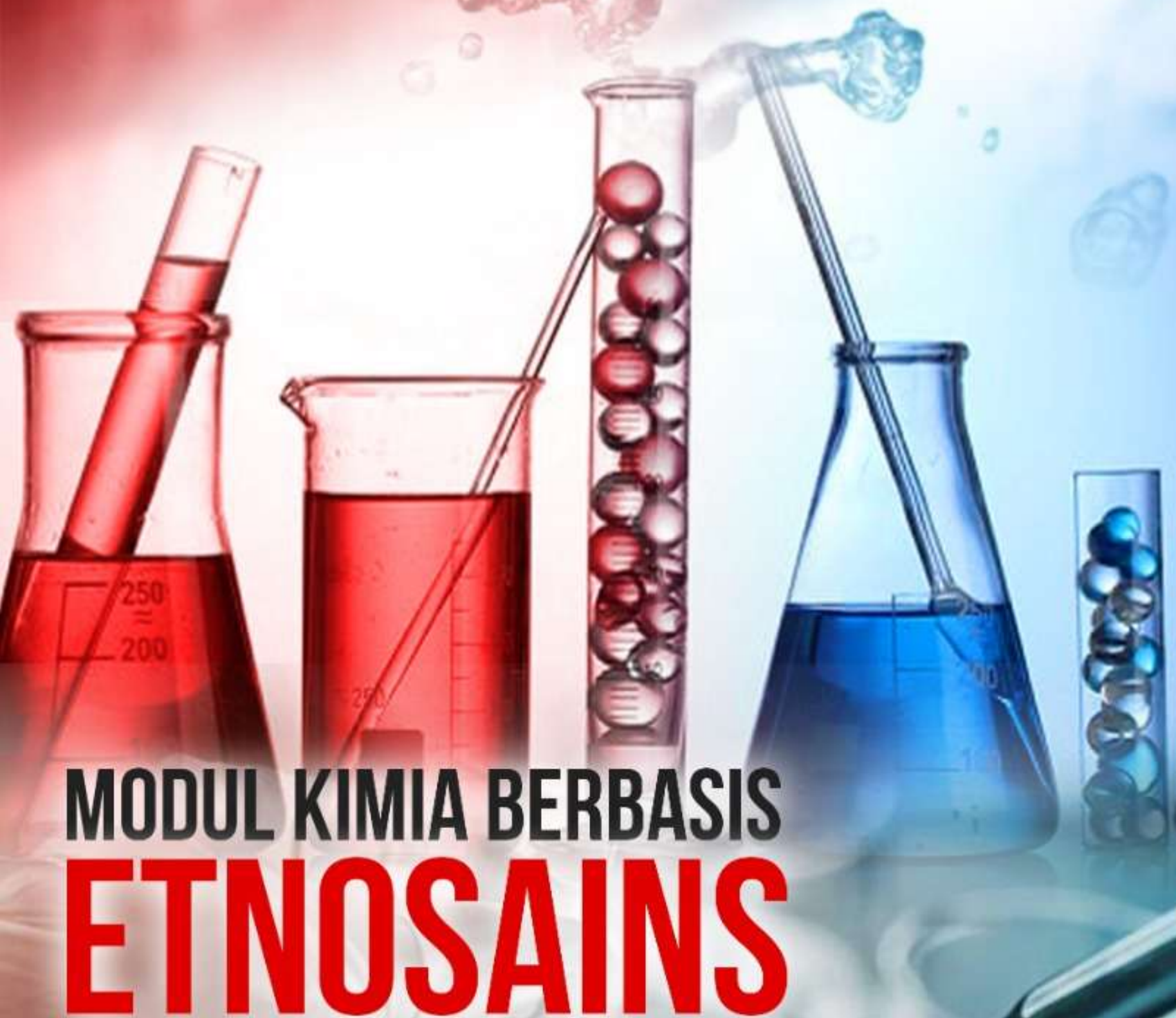

LARUTAN ASAM BASA P HIDROLISIS GARAM 2
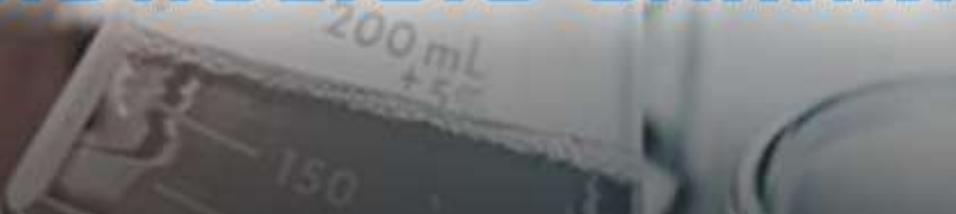


\section{MODUL KIMIA

Modul Kimia Berbasis Etnosains

\section{LARUTAN ASAM BASA \& HIDROLISIS GARAM}

Penyusun:

Rizki Utari (Email: rizkiutari408@gmail.com)

Dr. Yayuk Andayani, M,Si.

Dr. rer. nat. Lalu Rudyat Telly Savalas, M,Si.

Serta diarahkan oleh segenap Dosen Pendidikan IPA

Dengan dukungan keluarga \& teman seperjuangan Pascasarjana

Angkatan 2018

Desain Sampul:

Tra

Ukuran Modul: $17,6 \times 25 \mathrm{~cm}(\mathrm{~B} 5)$

Program Studi Magister Pendidikan IPA

Program Pascasarjana

Universitas Mataram

2020 


\section{KATA PENGANTAR}

Bismillahhirrahmannirrahim,

Alhamdulillah segla puji bagi Allah SWT yang telah memberikan karunia dan limpahan rahmat yang tiada henti-hentinya serta memberikan kemudahan dalam segala urusan sehingga modul kimia berbasis etnosains yang berjudul "Larutan Asam Basa \& Hidrolisis Garam" ini dapat terselesaikan. Sholawat dan salam tetap tercurahkan kepada insan paling mulia sepanjang masa "Nabi Muhammad SAW" Sang Penyejuk Jiwa yang telah mengantarkan kita ke zaman yang penuh dengan ilmu pengetahuan.

Modul kimia berbasis etnosains ini diharapkan dapat memberikan kontribusi bagi peningkatan kualitas pendidikan di Indonesia. Dengan menggunakan modul pelengkap ini, peserta didik akan lebih mengerti konsep dan aplikasi dari materi asam basa \& hidrolisis garam serta membentuk sikap konservasi peserta didik. Modul ini disusun secara sistematis dengan kajian etnosains menjadi bagian didalamnya. Etnosains yang diangkat dalam bentuk kebiasaan masyarakat dimana peserta didik akan diarahkan merekonstruksikan pengetahuan sains masyarakat menjadi pengetahuan sains ilmiah. Harapannya akan membentuk sikap konservasi lingkungan sebagai wujud peduli terhadap lingkungan dan cinta akan kekayaan budayanya.

Ucapan terimakasih penulis sampaikan kepada Ibu Dr. Yayuk Andayani, M.Si. dan Bapak Dr. rer. nat. L. Rudyat Telly Savalas, M.Si. yang telah membimbing penulis dengan penuh kesabaran dan ketulusan. Ucapan terimakasih juga penulis sampaikan kepada orang tua, kerabat, dan teman seperjuangan pascasarjana angkatan 2018, serta semua pihak yang telah membantu dalam menyelesaikan modul ini.

Penulis menyadari modul kimia berbasis etnosains ini masih terdapat banyak kekurangan, oleh karena itu kritik dan saran yang membangun senantiasa penulis nantikan. Kekurangan yang ada dalam modul ini semata-mata berasal dari penulis. Penulis berharap modul etnosains ini dapat memberikan manfaat terutama bagi generasi muda.

Puyung, Maret 2020 


\section{DAFTAR ISI}

hal.

Halaman Judul 1

Kata Pengantar 3

Daftar Isi 5

A. Petunjuk Penggunaan Modul ............................................

B. Karakteristik Modul 9

Kegitan Belajar 1. Aktivitas Etnosains 14 Ayo Mengingat

Ayo Menambah Wawasan

Kegitan Belajar 2. Materi …………………………............ 15

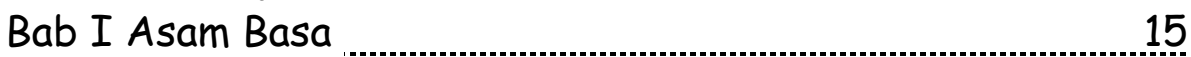

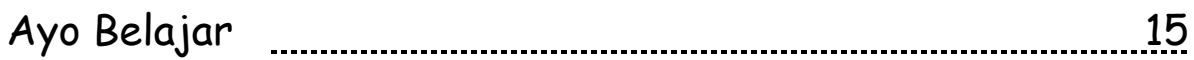

Konsep Asam Basa ............................................................... 15

Ayo Berjelajah Etnosains ........................................................ 23

Bab II Hidrolisis Garam ……........................................ 29

Ayo Mengingat _..................................................................... 29

Ayo Mencari Tahu …………………………………......... 29

Konsep Hidrolisis Garam ..................................................... 30

Sifat Garam Terhidrolisis ..................................................... 31

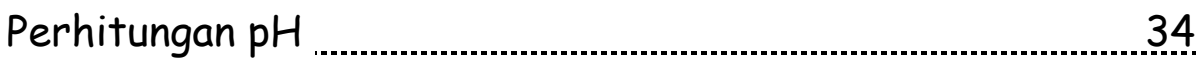

Ayo Observasi .................................................................... 36

Ayo Bereksperimen ……………………………………….... 37

Ayo Berjelajah Etnosains ...................................................... 39

Kegitan Belajar 3. Evaluasi ……………………................... 44

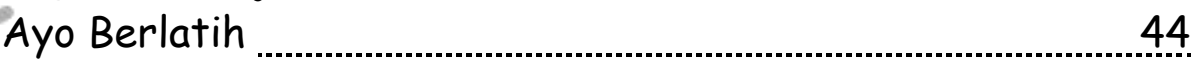

Umpan Balik \& Tindak Lanjut

Daftar Pustaka

Lampiran

Glosarium 


\section{MODUL KIMIA BERBASIS ETNOSAINS}

Let's start our journey

inside this module

"KARUNIA ALLAH YANG PALING LENGKAP

ADALAH KEHIDUPAN YANG DIDASARKAN PADA

ILMU PENGETAHUAN"

$\&$

"KESALAHAN TERBURUK ADALAH KETERTARIKAN KITA DENGAN KESALAHAN ORANG LAIN"

(ALIBINABI THALIB)
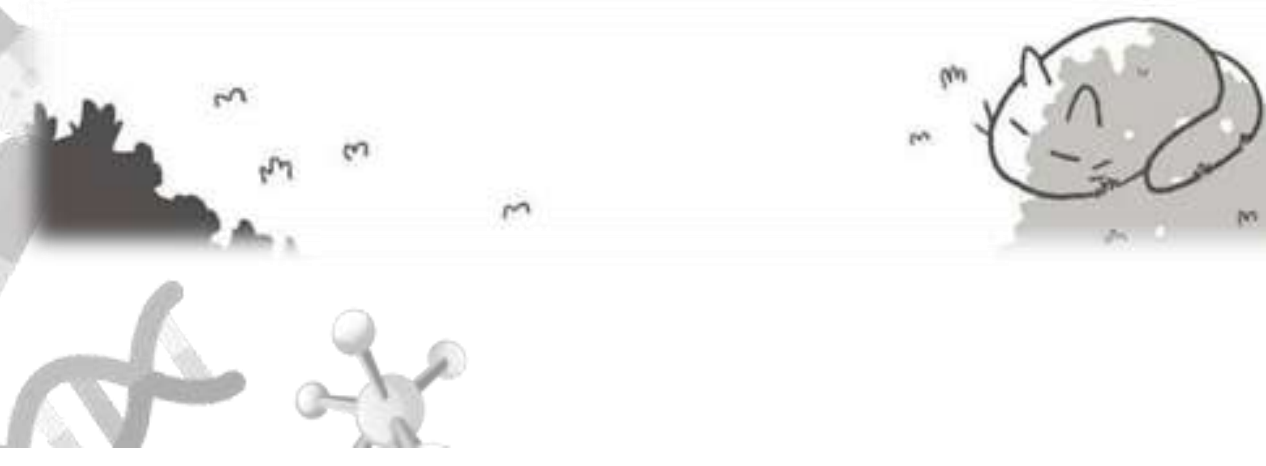


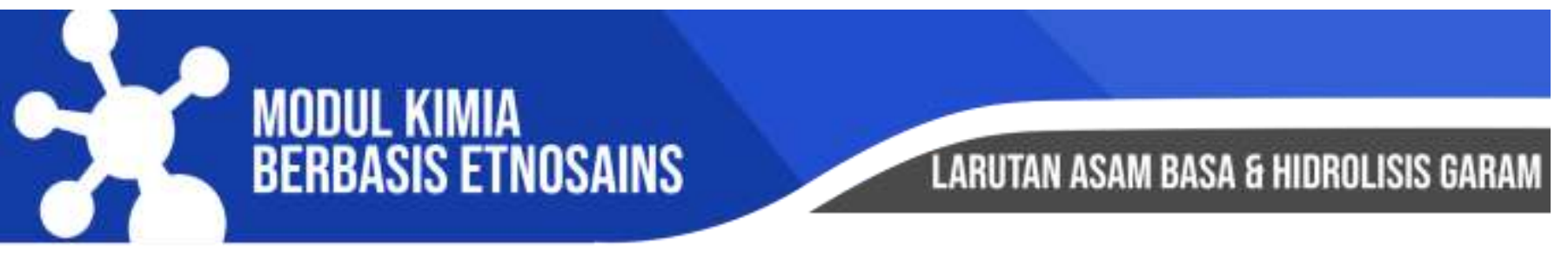

\section{A. PETUNJUK PENGGUNAAN MODUL}

Sebelum mempelajari modul kimia berbasis etnosains ini, Anda harus memperhatikan petunjuk penggunaan modul berikut untuk memperoleh hasil yang optimal.

1) Modul berisi: Pendahuluan (Petunjuk penggunaan Modul, Karakteristik Modul, Kompetensi Dasar, dan IPK), Materi Pembelajaran dan kegiatan etnosains (Ayo Mengingat, Ayo Mencari Tahu, Ayo Membaca, Ayo Observasi, Ayo Bereksperimen, Ayo Berjelajah Etnosains, Bacaan Etnokimia,), Penutup (Uji Pemahaman, Umpan Balik \& Tindak Lanjut, Daftar Pustaka, Lampiran, dan Glosarium).

2) Modul ini terdiri dari 3 Kegiatan Belajar.
a. Kegiatan Belajar ke-1 berisi aktivitas etnosains
b. Kegiatan Belajar ke-2 berisi materi pelajaran kimia
c. Kegiatan Belajar ke-3 berisi evaluasi

3) Memahami petunjuk belajar sehingga memperoleh hasil yang optimal.

\section{PETUNJUK BAGI SISWA}

Dalam kegiatan pembelajaran menggunakan modul kimia berbasis etnosains ini, siswa diharapkan:

1) Memahami tujuan pembelajaran yang akan dicapai.

2) Membaca "Rencana Belajar" yang terdapat dalam setiap "Kegiatan Belajar" sebelum mulai mempelajari materi dalam modul. 


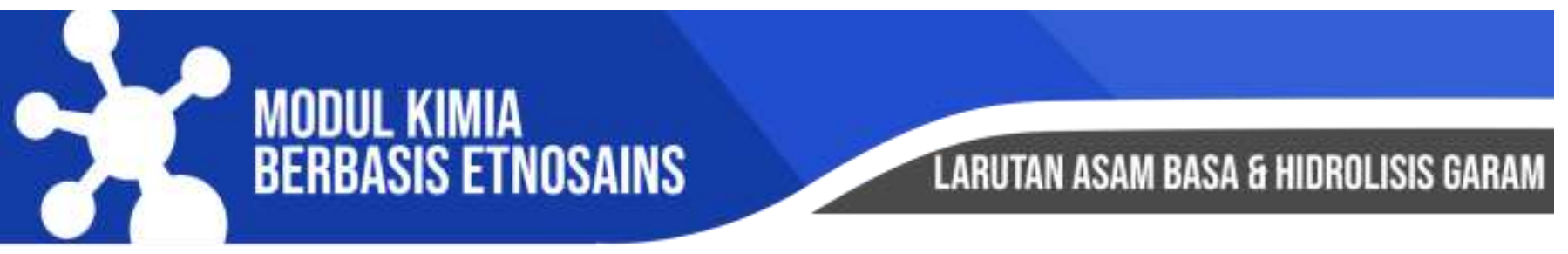

\section{PETUN.IUK BAGI SISWA}

3) Memahami dan melakukan bagian-bagian dalam modul yang meliputi kegiatan:

a) Ayo Mengingat yang mengajak anda mengamati kebiasaan yang terjadi di masyarakat yang faktual kemudian mencoba menganalisa sementara pengamatan anda dengan menbuat sebuah prediksi.

b) Ayo Mencari Tahu yang mengajak Anda untuk mengkaji berbagai literatur untuk menyelesaikan permasalahan yang ada

c) Ayo Membaca yang mangajak Anda untuk menambah wawasan dan menguatkan hasil analisa Anda, karena di dalamnya terdapat konsep yang dapat diterapkan dalam kehidupan nyata.

d) Ayo Observasi, yang mengajak Anda untuk melakukan observasi yaitu kegiatan mengumpulkan dari sebuah percobaan/ pengamatan yang anda lakukan.

e) Ayo Bereksperimen yang mengajak Anda mengaplikasikan apa yang sudah diamati dengan sebuah percobaan sederhana yang bertujuan untuk melatih sikap konservasi lingkungan.

f) Ayo Berjelajah Etnosains yang mengajak Anda untuk menambah wawasan terkait budaya sekitar dan mampu mengaplikasikannya ke dalam pembelajaran sains ilmiah di sekolah.

\section{PETUNJUK BAGI SISWA}

4) Mengerjakan latihan soal yang terdapat pada akhir kegiatan belajar dan tes formatif untuk mengetahui tingkat pemahaman materi terhadap materi yang telah dipelajari.

5) Mengukur kemampuan memahami materi dengan umpan balik dan tindak lanjut.

6) Mengulangi lagi kegiatan belajar atau bertanya pada guru jika belum menguasai capaian yang diharapkan.

7) Melanjutkan mempelajari kegiatan belajar selanjutnya apabila telah menguasai materi yang dipelajari. 


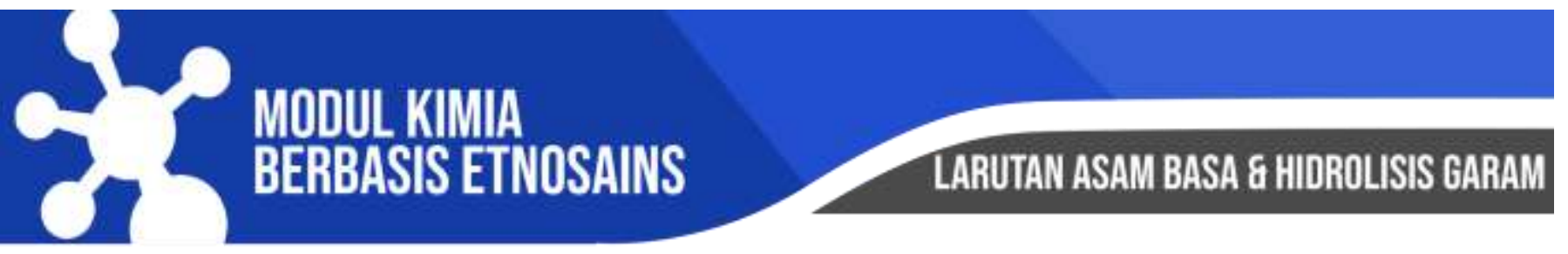

\section{B. KARAKTERISTIK MODUL}

\section{AKTIVITAS ETNOSAINS}

Mengarahkan siswa untuk mengkaitkan sains masyarakat dengan sains ilmiah dilengkapi dengan percakapan sebelumnya, yang memudahkan siswa untuk memahami aktivitas etnosains

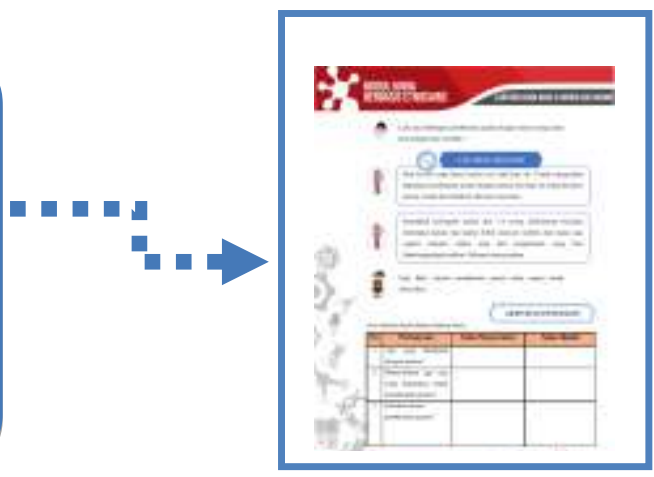

\section{PETA KONSEP}

Mengajak Anda untuk mengamati kedudukan materi, sehingga mengetahui letak materi dan prasyarat materi

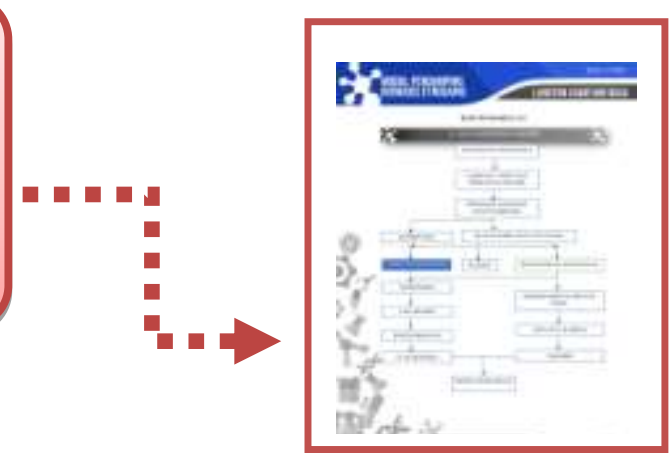

\section{PETUNJUK PENGGUNAAN} Mengajak Anda untuk memahami petunjuk belajar agar memperoleh hasil yang optimal

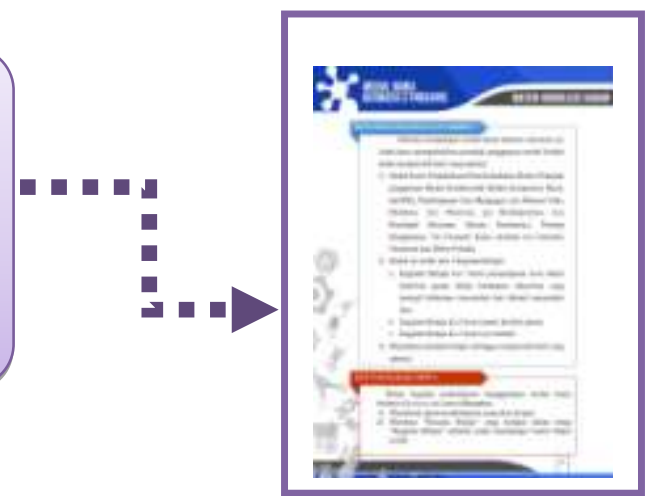




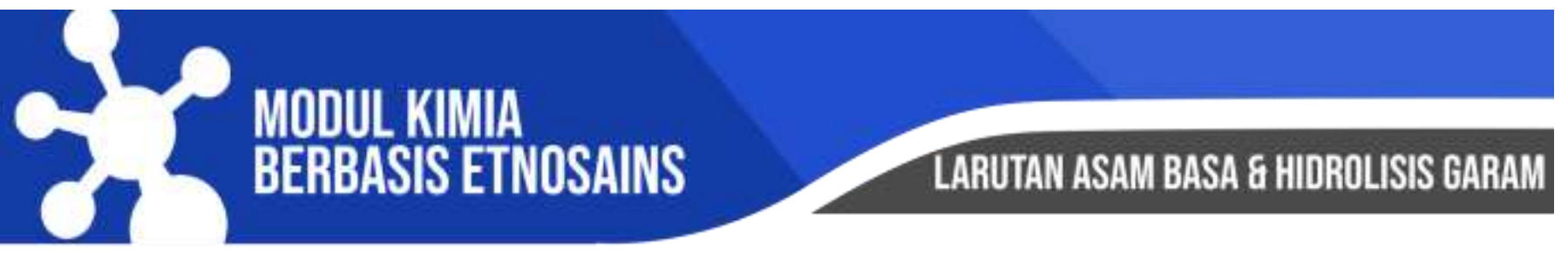

\section{AYO BERJELAJAH ETNOSAINS \\ Mengajak Anda untuk membuka wawasan untuk berjelajah dan mencari tahu informasi sains asli masyarakat yang bisa dikaitkan dengan sains ilmiah disekolah}

7. POJOK KONSERVASI Mengajak Anda peduli dan peka dengan lingkungan sekitar dan dapat melatih sejak dini pembentukan sikap konservasi

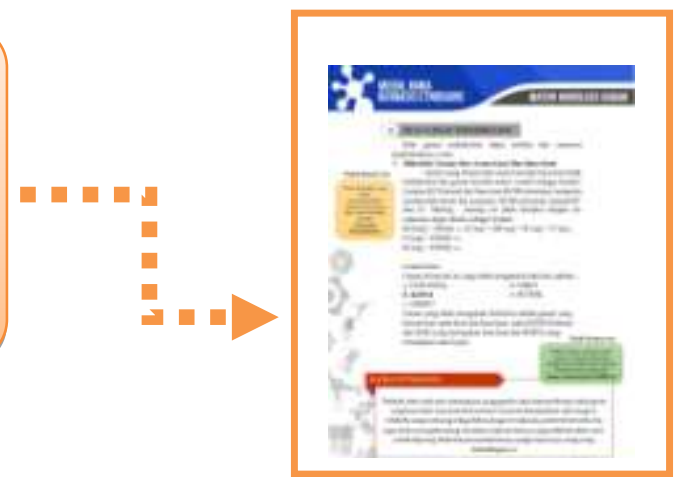




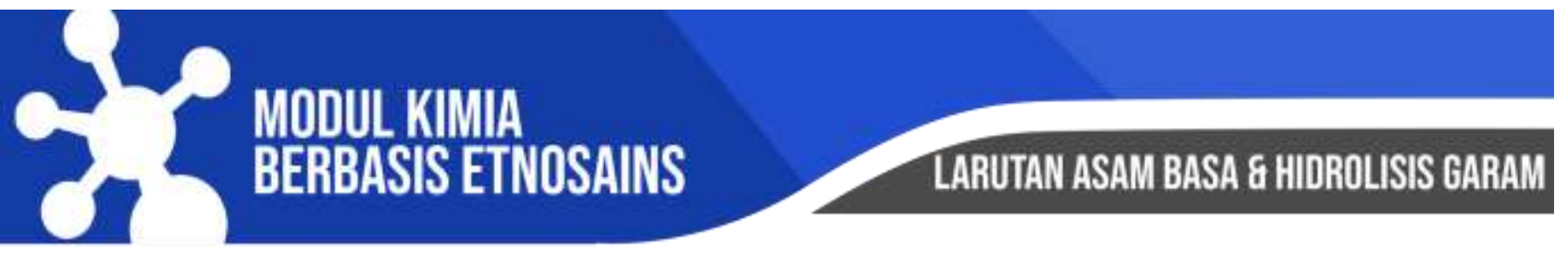

\section{PETAKONSEP}
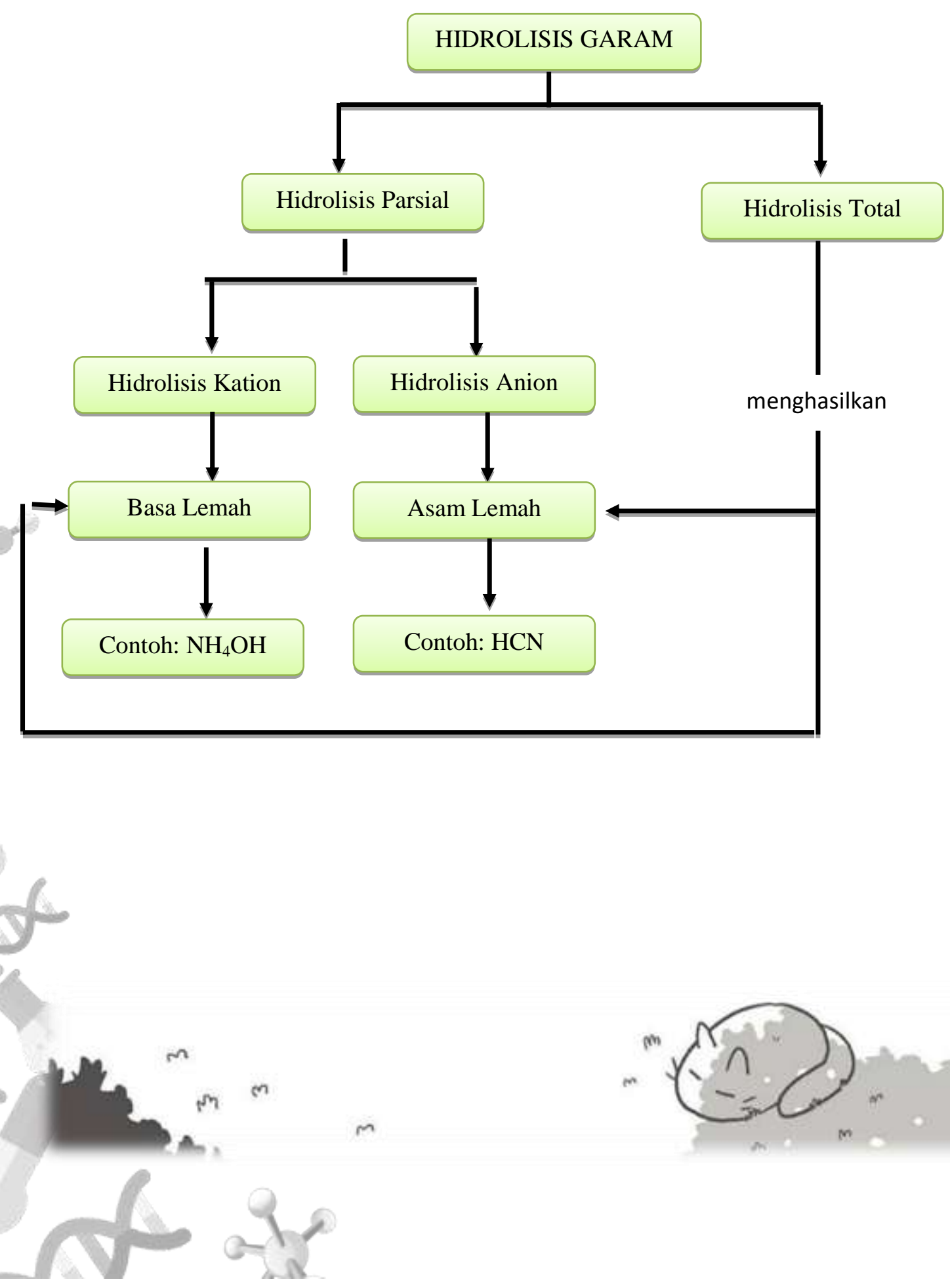


\section{A. KOMPETENSI DASAR (KD)}

3.12 Menganalisis garam-garam yang mengalami hidrolisis

4.12 Merancang, melakukan, dan menyimpulkan serta menyajikan hasil percobaan untuk menentukan jenis garam yang mengalami hidrolisis

\section{INDIKATOR PENCAPAIAN KOMPETENSI (IPK)}

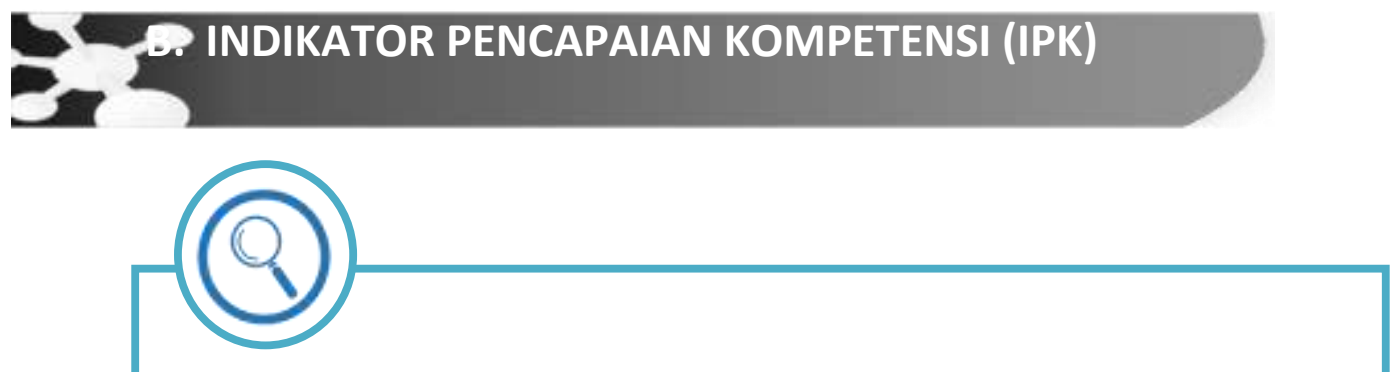

Setelah mempelajari modul ini, Anda diharapkan dapat:

* Menjelaskan konsep hidrolisis garam

* Menjelaskan macam-macam hidrolisis garam

* Menganalisis sifat garam

* Menuliskan persamaan reaksi hidrolisis garam

* Menentukan tetapan hidrolisis dan pH larutan

* Melakukan percobaan terkait pemanfaatan larutan garam dalam kehidupan sehari-hari yang berkaitan dengan kepercayaan dan kebiasaan masyarakat setempat

* Mendeskripsikan contoh pemanfaatan garam dalam kehidupan sehari-hari

* Menyajikan hasil percobaan dalam bentuk laporan tertulis untuk menentukan sifat dan jenis garam yang mengalami hidrolisis 


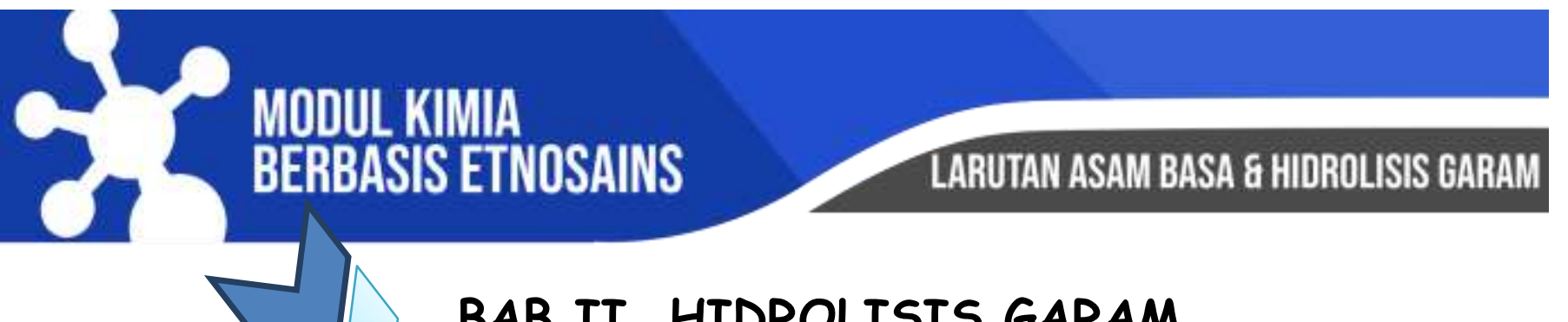

\section{BAB II. HIDROLISIS GARAM}

\section{Pojok Konservasi}

\section{"PROSES PEMBUATAN GARAM"}

Anak-anak, apa pendapat kalian tentang garam?

Garam digunakan sebagai bahan pangan Buk, berwarna putih seperti kristal

Garam merupakan bahan yang dipakai untuk masak sehari-hari, orang Sasak menyebutnya "sie geles" Buk. Saya pernah melihat di Sekotong tempat pembuatan garamnya Buk, di desa Cendimanik

Benar sekali, jadi garam ini digunakan setiap hari oleh orang tua kita dari dulu sampai sekarang untuk memasak.

Lalu, bagaimana proses pembuatan garam di Sekotong Buk?

Pertanyaan yang bagus, jadi tahap awal mereka akan mengambil tanah di telaga yang sudah mengering selama sekali dalam setahun dan disimpan di tempat yang disebut "bale", kemudian dilakukan pemapasan, perebusan, penyaringan, dan penjemuran sehingga nanti diperoleh garam yang dikenal dengan sebutan "sie geles". Bagaimana anak-anak, apa sudah paham atau ada pertanyaan? 


\section{C \\ BERBASISETNOSAINS}

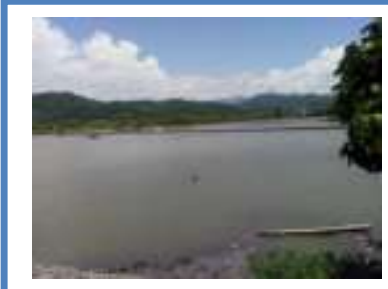

Air telaga

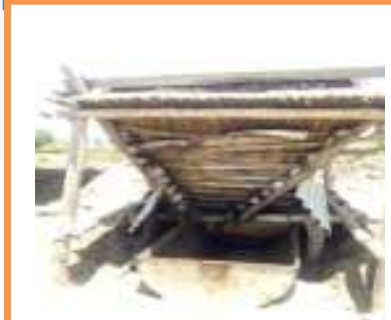

Pemapasan

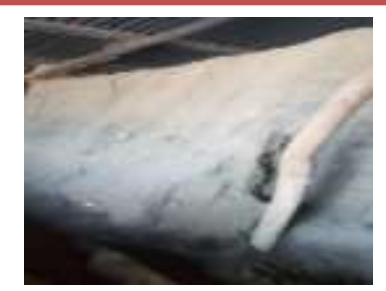

Tanah dari air telaga

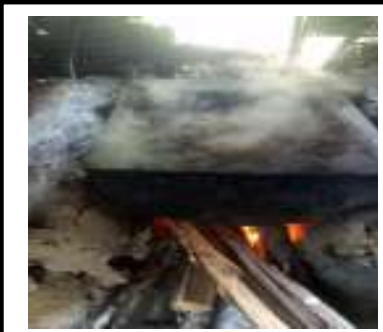

Perebusan

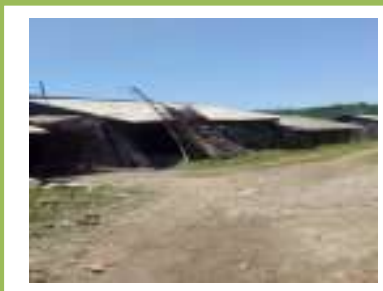

Bale penyimpanan

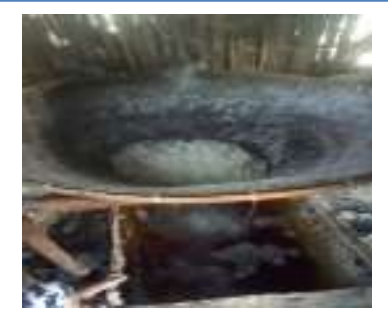

Penyaringan

Gambar 2.1 Proses pembuatan garam di desa Cendimanik, Sekotong

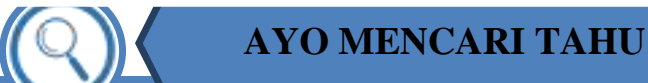

Nah itu lah yang harus kalian cari tahu hari ini. Untuk mengetahui hubungan pembuatan garam dengan materi kita hari ini yakni hirolisis garam, yuuuk kita lakukan aktivitas etnosains.

Bentuklah kelompok terdiri dari 3-4 orang. Diskusikan bersama kelompok kalian dan kalian boleh mencari sumber dari mana saja seperti internet, buku, atau dari pengalaman yang bisa dipertanggungjawabkan. Selamat mengerjakan.

Siap Buk, misteri pembuatan garam akan segera kami selesaikan. 


\section{MODUL KIMIA

AKTIVITAS ETNOSAINS

Ayo tuliskan hasil diskusi kalian disni.

\begin{tabular}{|c|l|l|l|}
\hline No & \multicolumn{1}{|c|}{ Pertanyaan } & Sains Masyarakat & Sains Ilmiah \\
\hline 1 & $\begin{array}{l}\text { Apa yang dimaksud } \\
\text { dengan garam? }\end{array}$ & & \\
\hline 2 & $\begin{array}{l}\text { Bahan-bahan apa saja } \\
\text { yang digunakan untuk } \\
\text { membentuk garam? }\end{array}$ & $\begin{array}{l}\text { Jelaskan proses } \\
\text { pembuatan garam? }\end{array}$ & \\
\hline 3 & $\begin{array}{l}\text { Pertanyaan } \\
\text { No }\end{array}$ & Sains Masyarakat & Sains Ilmiah \\
\hline 4 & $\begin{array}{l}\text { Apa jenis garam yang } \\
\text { terbentuk? }\end{array}$ & & \\
\hline 5 & $\begin{array}{l}\text { Apa saja kandungan } \\
\text { dalam garam tersebut? }\end{array}$ & & \\
\hline 6 & $\begin{array}{l}\text { Manakah yang } \\
\text { termasuk asam dan } \\
\text { basa? }\end{array}$ & & \\
\hline
\end{tabular}

Apa hubungan sifat asam basa dengan hidrolisis garam?. Diskusikan dan tulis kesimpulannya dengan kelompokmu. Selamat mengerjakan. 

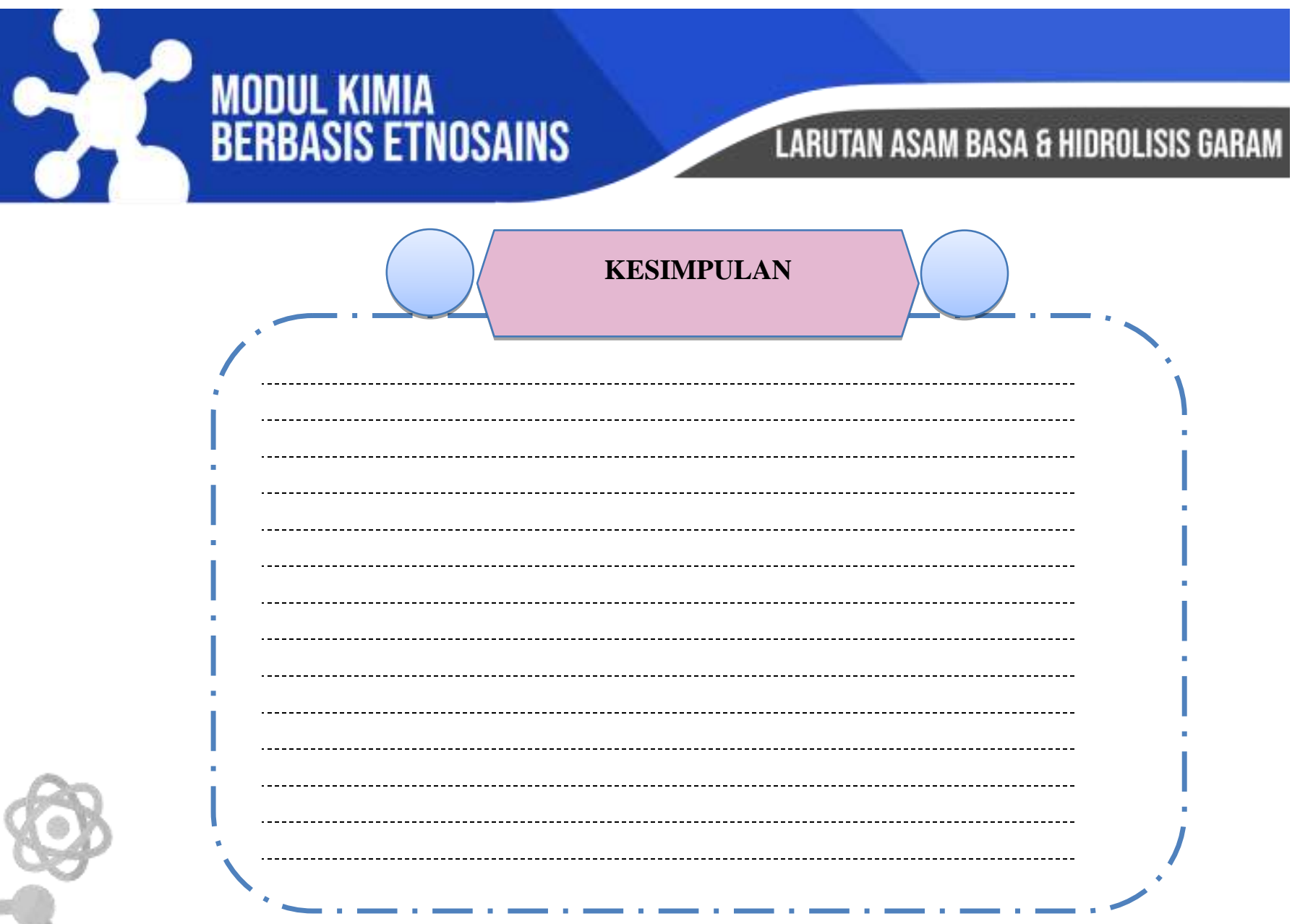


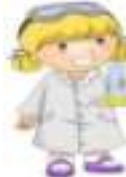

Pojok Konservasi

RENCANA PENYELIDIKKAN

What does saltwater affect plant growth? (https://youtu.be/VfW q5Y7ZAf0)

\begin{tabular}{|l|l|l|l|}
\hline NO & Nama Garam & Kegunaan & Sumber \\
\hline & & & \\
\hline & & & \\
\hline & & & \\
\hline & & & \\
\hline & & & \\
\hline & & & \\
\hline
\end{tabular}

\section{AYO MEMBACA}

\section{A KONSEP HIDROLISIS}

Garam merupakan zat yang dihasilkan dari reaksi netralisasi asam dan basa. Sifat larutan garam dapat dijelaskan dengan konsep hidrolisis. Hidrolisis merupakan reaksi penguraian yang terjadi antara kation dan anion garam dengan air dalam suatu larutan. Menurut konsep ini, komponen garam baik anion atau kation yang berasal dari basa lemah atau asam lemah akan berekasi dengan air (terhidrolisis). Hidrolisis kation akan menghasilkan ion $\mathrm{H}_{3} \mathrm{O}^{+}$atau $\mathrm{H}^{+}$, sedangkan hidrolisis anion akan menghasilkan ion $\mathrm{OH}^{-}$

\section{B SIFAT GARAM TERHIDROLISIS}

Sifat garam terhidrolisis dapat terlihat dari senyawa pembentuknya, yaitu:

\section{$>$ Hidrolisis Garam dari Asam Kuat dan Basa Kuat}

Garam yang berasal dari asam kuat dan basa kuat tidak terhidrolisis dan garam bersifat netral. contoh sebagai berikut: Larutan $\mathrm{KCl}$ berasal dari basa kuat $\mathrm{KOH}$ terionisasi sempurna membentuk kation dan anionnya. $\mathrm{KOH}$ terionisasi menjadi $\mathrm{H}^{+}$dan $\mathrm{Cl}$. Masing - masing ion tidak bereaksi dengan air, reaksinya dapat ditulis sebagai berikut.

$$
\begin{aligned}
& \mathrm{KCl}_{(\mathrm{aq})}+\mathrm{H}_{2} \mathrm{O}_{(\mathrm{l})} \leftrightarrow \mathrm{K}^{+}{ }_{(\mathrm{aq})}+\mathrm{OH}_{(\mathrm{aq})}^{-}+\mathrm{H}^{+}{ }_{(\mathrm{aq})}+\mathrm{Cl}^{-}(\mathrm{aq}) \\
& \mathrm{Cl}_{(\mathrm{aq})}^{-}+\mathrm{H} 2 \mathrm{O}_{(\mathrm{l})} \rightarrow \text { tidak terjadi reaksi }
\end{aligned}
$$




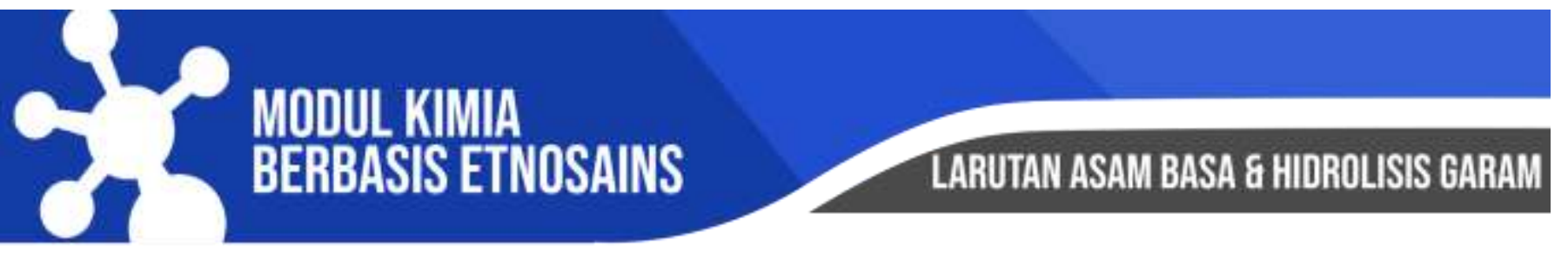

Garam yang kita gunakan ini biasanya $\mathrm{NaCl}$, garam ini akan membuat bawang yang telah dipotong-potong menjadi lebih awet Rin, kalau tidak ditambah garam bisa-bisa nanti rasanya jadi tidak enak, selain itu juga kita bisa simpan kalau bawangnya terlalu banyak. Kita bisa pakai buat besok deh

Kok bisa begitu ya Ra?

Karena garam ini memiliki kemampuan sebagai zat higroskopis sehingga sel organisme mati dan makanan tetap awet

Dari percakapan Rara dan Rini, Yuuuk kita simpulkan sains masyarakat dan sains ilmiah yang diperoleh

\begin{tabular}{|c|l|l|l|}
\hline No & Pertanyaan & \multicolumn{1}{|c|}{ Sains Masyarakat } & \multicolumn{1}{|c|}{ Sains Ilmiah } \\
\hline 1 & $\begin{array}{l}\text { Apa saja } \\
\text { macam-macam } \\
\text { garam? }\end{array}$ & $\begin{array}{l}\text { Garam halus (sie geles) } \\
\text { dan garam kasar (sie } \\
\text { gotok) }\end{array}$ & $\begin{array}{l}\text { Garam yang dikenal oleh } \\
\text { masyarakat pada umunya adalah } \\
\text { garam natrium klorida, namun } \\
\text { garam ini ada banyak macamnya } \\
\text { berdasarkan asalanya yakni } \\
\text { garam yang berasal dari asam } \\
\text { kuat dan basa kuat, asam kuat } \\
\text { dan basa lemah, basa kuat dan } \\
\text { asam lemah, dan asam lemah dan } \\
\text { basa lemah }\end{array}$ \\
$\begin{array}{l}\text { Kenapa garam } \\
\text { dapat digunakan } \\
\text { sebagai } \\
\text { pengawet } \\
\text { makanan }\end{array}$ & $\begin{array}{l}\text { Ini } \\
\text { kebiasaan yang sudah } \\
\text { dilakukan secara turun- } \\
\text { temurun }\end{array}$ & $\begin{array}{l}\text { Garam bersifat hidgroskopis } \\
\text { artinya mampu menyerap air di } \\
\text { dalam sel organisme sehingga sel } \\
\text { mengalami dehidrasi dan } \\
\text { akhirnya bakteri di dalamnya } \\
\text { mati dan tidak dapat berkembang } \\
\text { biak. Misalnya garam NaCl yang } \\
\text { digunakan ini merupakan garam }\end{array}$ \\
&
\end{tabular}




\begin{tabular}{|c|c|c|c|}
\hline & & & $\begin{array}{l}\text { yang berasal dari asam kuat dan } \\
\text { basa kuat artinya akan } \\
\text { membentuk garam dan air, } \\
\text { sehingga jika dibiarkan dalam } \\
\text { keadaan terbuka garam ini akan } \\
\text { basah karena kemampuannya } \\
\text { dalam menyerap air dan bisa } \\
\text { digunakan sebagai pengawet }\end{array}$ \\
\hline 3 & $\begin{array}{l}\text { Apa } \\
\text { hubungannya } \\
\text { dengan materi } \\
\text { hidrolisis garam? }\end{array}$ & $\begin{array}{l}\text { Garam merupakan salah } \\
\text { satu bahan kimia, } \\
\text { sehingga berhubungan } \\
\text { dengan materi asam } \\
\text { basa }\end{array}$ & $\begin{array}{l}\text { Garam yang digunakan oleh Rara } \\
\text { dan Rini yakni } \mathrm{NaCl} \text { (natrium } \\
\text { klorida) yang berasal dari asam } \\
\text { kuat (HCl) dan basa kuat } \\
(\mathrm{NaOH}) \text { artinya tidak mengalami } \\
\text { hidrolisis karena garam } \\
\text { terionisasi sempurna yakni } \\
\text { membentuk } \mathrm{Na}^{+} \text {dan } \mathrm{Cl}^{-}\end{array}$ \\
\hline
\end{tabular}

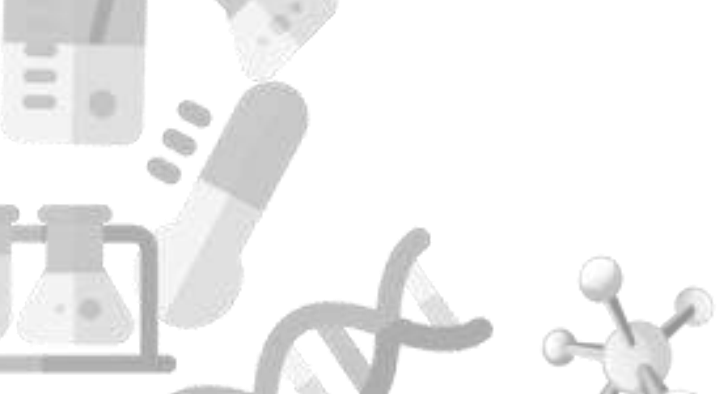




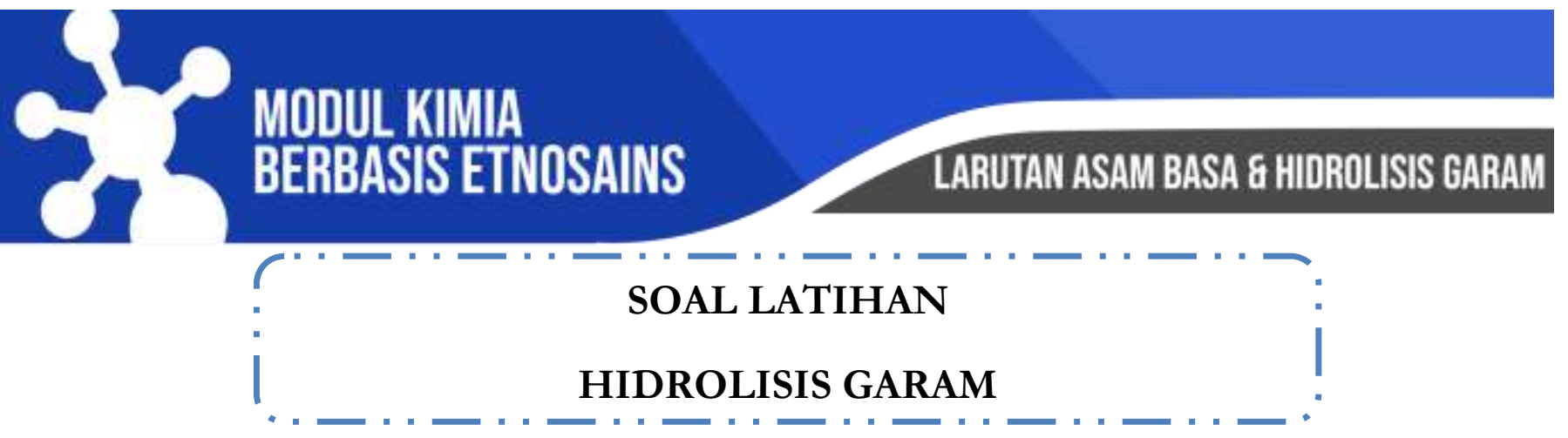

\section{PILIHAN GANDA}

1) Berikut adalah beberapa larutan:
(1) $\mathrm{KNO}_{3}$
(2) $\mathrm{NH}_{4} \mathrm{Cl}$
(3) $\mathrm{Na}_{2} \mathrm{SO}_{4}$ (4) $\mathrm{Na}_{2} \mathrm{CO}_{3}$
(5) $\mathrm{CH}_{3} \mathrm{COOK}$ Pasangan garam yang bersifat netral ditunjukkan oleh nomor....
a. (1) dan (3)
b. (2) dan (3)
c. (2) dan (4)
d. (3) dan (4)

2) Tetapan hidrolisis garam (kh) dapat dirumuskan dari persamaan.....
a. $K_{h}=\frac{K_{b}}{K_{a}}$
c. $K_{h}=\frac{K_{a}}{K_{w}}$
b. $K_{h}=\frac{K_{w}}{K_{a} K_{b}}$
d. $K_{h}=\frac{K_{a} K_{b}}{K_{w}}$
e. $K_{h}=K_{w} x K_{a}$

3) Berikut contoh pemanfaatan hidrolisis garam dalam kehidupan sehari-hari kecuali
a. Batik
b. Tradisi nginang
c. Pembersih ketombe
d. Tradisi Betawi (roti buaya)

4) Untuk mendapatkan larutan garam yang $\mathrm{pH}$-nya 9 , maka banyaknya garam natrium benzoat $\mathrm{C}_{6} \mathrm{H}_{5} \mathrm{OONa}$ yang harus dilarutkan dalam $100 \mathrm{~mL}$ air adalah... (Ka $\mathrm{C}_{6} \mathrm{H}_{5} \mathrm{OONa}=6 \times 10^{-5} \mathrm{~m}$ dan $\left.\mathrm{Mr}_{6} \mathrm{H}_{5} \mathrm{OOH}=144\right)$
a. 0,54 gram
b. 1,08 gram
c. 2,16 gram
d. 8,64 gram

5) Jika $200 \mathrm{~mL} \mathrm{NH} \mathrm{NH}_{4} \mathrm{OH} 0,8 \mathrm{M}$ direaksikan dengan $200 \mathrm{~mL}$ larutan $\mathrm{HCl} 0,8 \mathrm{M}, \mathrm{Kb}$ $\mathrm{NH}_{4} \mathrm{OH}=10-5, \mathrm{pH}$ campuran setelah bereaksi adalah....
a. $5-\log 2$
b. $5-\log 3$
c. $5-\log 4$
d. $5-\log 5$

6) Jika dua larutan masing-masing mengandung $25 \mathrm{~mL}$ Jika dua larutan masingmasing mengandung $25 \mathrm{~mL} \mathrm{NaOH} 0,2 \mathrm{M}$ dan $25 \mathrm{~mL} \mathrm{CH}_{3} \mathrm{COOH} \mathrm{0,2} \mathrm{M}$ dengan $\mathrm{COOH}^{-} 0,2 \mathrm{M}$ dengan $\mathrm{Ka} \mathrm{CH} 3 \mathrm{COOH}=10^{-5}$ dicampurkan, maka $\mathrm{pH}$ nya adalah...
a. 3
b. 4 
